\title{
Secondary School Students' Attitudes toward the Geography Course
}

\author{
Nadire Karademir \\ Department of Geography, Faculty of Science and Letters, Kahramanmaras Sutcu Imam University, Turkey
}

Received March 28, 2020; Revised April 21, 2020; Accepted May 3, 2020

Copyright $@ 2020$ by authors, all rights reserved. Authors agree that this article remains permanently open access under the terms of the Creative Commons Attribution License 4.0 International License

\begin{abstract}
The objective of this study is to identify whether there is a statistically significant difference in secondary school students' attitudes toward the geography course on the basis of certain variables. The sample of the study was composed of a total of 899 students including 509 female students and 390 male students. The data were obtained through the 'Personal Information Form' which was created by the researcher and the 'Attitude Scale'. The findings demonstrated that there was a statistically significant difference in the attitude scores on the basis of the variables of 'age', 'class year', 'participation in geography field trips', 'satisfaction with teacher's use of student-centered active teaching in the course', 'playing orienteering game', 'use of social media', 'establishing relationship between media and geography' and 'establishing relationship between daily life and geography'. In conclusion, it was found that, in general, the secondary school students had moderately positive attitudes toward the geography course. It may be asserted that the female and male students developed similar attitudes towards the geography course. In addition to this, in this study, it was found that participation in geography trips positively affected the participants' desire to learn. Moreover, it was observed that the students who established a relationship between geography and daily life had a more positive attitude towards the geography course. Furthermore, the students who could establish a relationship between media and geography showed a much more positive attitude towards the geography course. It was determined that the secondary school students who were able to associate movies, TV series, news and game shows with geography had more positive attitudes towards the geography course.
\end{abstract}

Keywords Education, Geography, Social Media

\section{Introduction}

Climates, landforms, plant cover, the human settings, space inhabited by human beings and several other topics are addressed within the scope of the geography course. In societies familiar with these topics, in other words, in societies with a high level of geographic literacy, people are transformed into individuals who are equipped with the sense of responsibility on national and international levels, are endowed with high quality of life and are well-qualified [1]. Geography is "the science of studying and analyzing the interaction between human beings and their natural environment, focusing on incidents and situations which come into play alongside these interactions in accordance with distribution, correlation, comparison, causation principles and through application of various research methods, and subsequently putting forward the obtained results as a synthesis" [2]. Getting well-informed about issues of geography and putting them into practice are essential to become a good citizen. It is suggested that geographic literacy occupies a crucial role in formation of people's national identity [3]. The geography course helps raise people as sensitive human beings by informing them about the causes and effects of physical, anthropic, economic and political events taking place across the world [4]. Instruction of the geography course enables students to develop the sense of responsibility assumed consciously for development of their country and tempts them to get acquainted with their world and country [5]. People's learning of geography begins with establishment of a link between the human being and space. The Geography Course Curriculum implemented at secondary schools in Turkey aims to empower students to achieve in a planned manner in acquiring information and skills referred to in the program. It attaches importance to development of geographic questioning skills in the framework of the interaction between the human being and nature [6]. Additionally, today, geographic skills offer a platform of presenting essential, up-to-date and useful knowledge to well-informed and functional societies [7]. Furthermore, it is asserted that 'geographic information technologies' will be one of the three most needed tools in decision-making processes in the 
$21^{\text {st }}$ century [8].

In Turkey, instruction of geography starts in the pre-school period and continues until university. It is pretty imperative work. However, the criticism that is neglected in Turkey is worth consideration [9]. In view of the fact that geography may provide students with highly crucial achievements, students should be urged to adopt a more positive approach toward this course. It is essential that geography is not simply perceived as a course but is configured in a way to be mixed with life. Thus, the sustainability and continuity in relation to instruction of the geography course will be assured. Countries interested in being developed almost in all areas, particularly the societal, economic and environmental areas, should benefit from the science of geography. Education assumes the most important task, that is, empowering human beings to be successful in their lives. Education will help human beings adapt to the changing conditions and the society in which they live. For assuring that education reaches its targets and makes contributions to human life, people's attitudes towards education and instruction are characterized as some of the most essential variables. In this respect, identifying students' attitudes towards the geography course and shaping their negative attitudes in the positive direction are of utmost importance.

Attitude may be described as 'inclinations which cannot be observed but assumed to be giving rise to certain behaviors which can be observed' [10], 'pattern of behavior which the individual is expected to manifest as a response to any stimulant such as a situation, incident, object and phenomenon' [11] and 'a tendency which is expressed in relation to an object, is exhibited to a certain extent and manifests itself positively or negatively' [12]. Attitude is an inclination which organizes an individual's feelings, thoughts and behaviors in relation to objects, ideas, institutions, incidents and other human beings. It appertains to the individual and assures that the individual is consistent in their feelings, thoughts and behaviors [13]. Hence, it is of paramount importance to the fields of education and instruction. Attitudes have three aspects, namely, cognitive, emotional and behavioral aspects. Their cognitive aspect pertains to thoughts and beliefs in relation to an object or situation. It is the state of being cognizant and of cognition. The emotional aspect is the state of feeling annoyed or pleased in reaction to a situation. It is the case that the human being evaluates an individual or object. The third aspect is effort, and it is the inclination to take action to behave [12, 14]. The attitude assumed at the beginning of a mission affects the result of this mission more than all other factors do [15]. Transforming attitudes in the positive or negative direction may be achieved through education.

Attitude towards the geography course may be described as the positive or negative emotion felt by the individual toward the geography course. For the geography course to reach the goals targeted for students, students' attitudes towards this course need to be positive. Prior to secondary education, students are introduced to topics of geography through different disciplines (courses of Social Studies, Life Sciences, Science and Technology) at the first and second stages of primary education. Whether students' attitudes are positive or negative pertains to whether they are interested in the geography course or not. In order to tempt students to like the course and be interested in it, important duties are imposed on the geography teacher. It may be deduced that, if the student is active and interested in the geography course, then they have a positive attitude towards the geography course. If, however, the student who is not enthusiastic about the course, fails to fulfill homework assignments or is incapable of participating in the course actively, then they have a negative attitude towards the geography course.

One of the most crucial factors determining the effectiveness and efficiency of the geography course in secondary education is the positive or negative attitude developed by students towards the geography course. These attitudes make up one of the crucial issues influencing students' interest in geography, eagerness and leaning toward the course and achievements in the course. The attitude developed by students towards stimulants such as the course, the teacher and the school in the process of education and instruction has an effect on the students' academic achievements. Students who have positive attitudes toward the school or the course are more successful than students who have negative attitudes [16].

The objective of this study is to find out whether there is a statistically significant difference in secondary school students' mean scores of attitude toward the geography course on the basis of certain variables. Moreover, it is thought that the findings will allow instructors to understand students' attitudes towards the geography course and enhance the usefulness of geography instruction in daily life. Thus, problems coming into play in the geography instruction process will be identified, and solutions will be proposed.

\section{Materials and Methods}

The quantitative research method of descriptive-survey was used in this study, which was conducted with secondary school students. Events, objects, essences and groups are aimed to be described and explained with the descriptive-survey method [17].

\subsection{Sample}

The sample of the study included a total of 899 students who agreed to participate in the study on a voluntary basis and were enrolled in the $9^{\text {th }}, 10^{\text {th }}, 11^{\text {th }}$ and $12^{\text {th }}$ grades of secondary schools in the province of Kahramanmaras in Turkey in the academic year of 2018-2019. Among the 899 participants, 509 were female, and 390 were male. In the sample selection process, attention was paid to collection of data from different types of secondary schools (Anatolian High School, Science High School, Social Science High 
School, Health Vocational High School, Vocational High School, Imam Hatip (Islamic Vocational) High School and so on).

\subsection{Data Collection}

In the study, a questionnaire form was used as the data collection tool. This questionnaire consisted of two parts. There was a personal information form in the first part. In the second part, there was the Attitude Scale. The 'Personal Information Form' was created by the researcher, and the 'Attitude Scale' was created by Demir and Koç [18] who developed the scale for the purpose of evaluating attitudes towards the geography course and performed the validity and reliability study for the scale. 'The Scale of Attitude toward the Geography Course' is composed of two sub-scales including 15 items in total, that is, the 'affection and liking' sub-scale (9 items) and the 'willingness to learn' sub-scale (6 items). It is a 5-point Likert-type scale scored as ' 1 - I absolutely disagree', '2 - I disagree', '3 - Neutral', '4 - I agree' and ' 5 - I absolutely agree'.

\subsection{Data Analysis}

The data obtained through the scale were normally distributed. Thus, parametric tests were applied. In the analysis of the secondary school students' attitudes towards the geography course, 't-test' and 'One-Way ANOVA' were utilized. 'Scheffe Test' and 'LSD Test' were used in order to find out between which groups there were statistically significant differences in the context of bilateral comparisons which were carried out after the analysis of variance. The Cronbach's Alpha coefficients were found as 0.912 and 0.888 respectively for the 'affection and liking' sub-scale and the 'willingness to learn' sub-scale. The level of statistical significance was set as $5 \%(\mathrm{p}<0.05)$.

\section{Findings}

The data obtained from the sample were analyzed through proper test methods and are presented in the following tables.

As seen in Table 1, on the basis of the 'gender' variable, it was ascertained that, between the male and female participants of the sample, there was no statistically significant difference in the mean scores obtained from the 'affection and liking' and 'willingness to learn' sub-scales of the Attitude Scale.

Table 1. Statistics for the analysis of the sample on the basis of the 'gender' variable

\begin{tabular}{|l|l|l|l|l|c|c|}
\hline Sub-scale & Gender & N & Mean & SD & P \\
\hline \multirow{2}{*}{ Affection and Liking } & Male & 390 & 34.87 & 7.19 & 1.461 \\
\cline { 2 - 5 } & Female & 509 & 34.18 & 6.75 & 0.144 \\
\hline \multirow{2}{*}{ Willingness to Learn } & Male & 390 & 19.90 & 6.25 & 0.377 \\
\cline { 2 - 5 } & Female & 509 & 19.75 & 5.65 & \multirow{2}{*}{0.707} \\
\end{tabular}

Table 2. Statistics for the analysis of the sample on the basis of the 'age' variable

\begin{tabular}{|c|c|c|c|c|c|c|c|}
\hline Sub-scale & Age & $\mathrm{N}$ & Mean & SD & $\mathrm{F}$ & $\mathrm{P}$ & Post Нос (Scheffe) \\
\hline \multirow{6}{*}{ Affection and Liking } & 13 & 7 & 32.14 & 5.79 & \multirow{6}{*}{$3.618 *$} & \multirow{6}{*}{$0.003^{*}$} & \multirow{6}{*}{$14-15 ; 14-16$} \\
\hline & 14 & 144 & 36.01 & 6.72 & & & \\
\hline & 15 & 303 & 34.00 & 7.17 & & & \\
\hline & 16 & 234 & 33.50 & 6.99 & & & \\
\hline & 17 & 134 & 34.89 & 6.61 & & & \\
\hline & 18 & 77 & 35.96 & 6.41 & & & \\
\hline \multirow{6}{*}{ Willingness to Learn } & 13 & 7 & 19.43 & 2.23 & \multirow{6}{*}{$3.662 *$} & \multirow{6}{*}{$0.003^{*}$} & \multirow{6}{*}{$15-18 ; 16-18$} \\
\hline & 14 & 144 & 20.93 & 6.03 & & & \\
\hline & 15 & 303 & 19.24 & 5.90 & & & \\
\hline & 16 & 234 & 19.28 & 6.19 & & & \\
\hline & 17 & 134 & 19.77 & 5.87 & & & \\
\hline & 18 & 77 & 21.74 & 4.58 & & & \\
\hline
\end{tabular}

${ }^{*} \mathrm{p}<0.05$ 
As seen in Table 2, on the basis of the 'age' variable, it was found that, between the age categories of the sample, there was a statistically significant difference in the mean scores obtained from the 'affection and liking' and 'willingness to learn' sub-scales of the Attitude Scale. With the ANOVA and Scheffe tests, it was discerned that the students aged 14 years had more positive attitudes towards the geography course than those aged 15 and 16 years in terms of the 'affection and liking' sub-scale, while the students aged 18 years had more positive attitudes towards the geography course than those aged 15 and 16 years in terms of the 'willingness to learn' sub-scale.

As seen in Table 3, on the basis of the 'class year' variable, it was discerned that, between the class years of the sample, there was a statistically significant difference in mean scores obtained from the 'affection and liking' and 'willingness to learn' sub-scales of the Attitude Scale. With the ANOVA and Scheffe tests, it was found that the $9^{\text {th }}$ and $12^{\text {th }}$ grade students had more positive attitudes towards the geography course than the $10^{\text {th }}$ grade students in terms of the 'affection and liking' sub-scale, while, in terms of 'willingness to learn' sub-scale, the $10^{\text {th }}$ grade students had more positive attitudes towards the geography course than the $9^{\text {th }}$ and $12^{\text {th }}$ grade students. Likewise, the $11^{\text {th }}$ grade students had more positive attitudes toward geography course than the $9^{\text {th }}$ grade students.

As seen in Table 4, on the basis of the 'school type' variable, it was discerned that, between the school types of the sample, there was a statistically significant difference in mean scores obtained from the 'affection and liking' and 'willingness to learn' sub-scales of the Attitude Scale. As a result of the ANOVA and Scheffe tests, it was ascertained that the Anatolian High School, Imam Hatip High School, Health Vocational High School and Social Science High School students had more positive attitudes towards the geography course than the Science High School students in terms of the 'affection and liking' sub-scale, while the Social Science High School students had more positive attitudes towards the geography course than the Anatolian High School, Science High School, Imam Hatip High School and Health Vocational High School students in terms of the 'willingness to learn' sub-scale.

Table 3. Statistics for the analysis of the sample on the basis of the 'class year' variable

\begin{tabular}{|c|c|c|c|c|c|c|c|}
\hline Sub-scale & Class Year & $\mathrm{N}$ & Mean & SD & $\mathrm{F}$ & $\mathrm{p}$ & $\begin{array}{l}\text { Post Hoc } \\
\text { (Scheffe) }\end{array}$ \\
\hline \multirow{4}{*}{ Affection and Liking } & 9 & 248 & 36.06 & 6.92 & \multirow{4}{*}{9.789} & \multirow{4}{*}{$0.000 *$} & \multirow{4}{*}{$9-10,12-10$} \\
\hline & 10 & 358 & 33.08 & 7.09 & & & \\
\hline & 11 & 197 & 34.62 & 6.55 & & & \\
\hline & 12 & 96 & 35.28 & 6.28 & & & \\
\hline \multirow{4}{*}{ Willingness to Learn } & 9 & 248 & 5.71 & 5.71 & \multirow{4}{*}{10.873} & \multirow{4}{*}{$0.000^{*}$} & \multirow{4}{*}{$\begin{array}{c}9-10,9-11,10-12,1 \\
1-9,12-10\end{array}$} \\
\hline & 10 & 358 & 6.02 & 6.02 & & & \\
\hline & 11 & 197 & 6.05 & 6.05 & & & \\
\hline & 12 & 96 & 4.76 & 4.76 & & & \\
\hline
\end{tabular}

${ }^{*} \mathrm{p}<0.05$

Table 4. Statistics for the analysis of the sample on the basis of the 'school type' variable

\begin{tabular}{|c|c|c|c|c|c|c|c|}
\hline Sub-scale & School Type & $\mathrm{N}$ & Mean & SD & $\mathrm{F}$ & $\mathrm{p}$ & Post Hoc (Scheffe) \\
\hline \multirow{5}{*}{ Affection and Liking } & Anatolian High School & 464 & 34.16 & 6.93 & \multirow{5}{*}{8.068} & \multirow{5}{*}{$0.000^{*}$} & \multirow{5}{*}{$\begin{array}{l}\text { F-A,F-Sa,F-İ,F-S } \\
\text { So-F,İ-F,Sa-AS-F }\end{array}$} \\
\hline & Science High School & 121 & 31.95 & 7.34 & & & \\
\hline & Health Vocational High School & 73 & 35.21 & 6.60 & & & \\
\hline & Imam Hatip High School & 114 & 36.11 & 5.37 & & & \\
\hline & Social Science High School & 127 & 36.14 & 7.28 & & & \\
\hline \multirow{5}{*}{ Willingness to Learn } & Anatolian High School & 464 & 19.17 & 6.05 & \multirow{5}{*}{12.457} & \multirow{5}{*}{$0.000^{*}$} & \multirow{5}{*}{$\begin{array}{c}\text { A-S,A-İ,A-S, } \\
\text { F-S,F-İ,F-S, } \\
\text { S-A,S-F } \\
\text { İ-A,İ-F } \\
\text { S-A,S-F }\end{array}$} \\
\hline & Science High School & 121 & 17.75 & 5.80 & & & \\
\hline & Health Vocational High School & 73 & 21.35 & 5.83 & & & \\
\hline & Imam Hatip High School & 114 & 21.57 & 4.87 & & & \\
\hline & Social Science High School & 127 & 21.65 & 5.36 & & & \\
\hline
\end{tabular}

${ }^{*} \mathrm{p}<0.05$ 
As seen in Table 5, on the basis of the 'participation in geography field trips' variable, it was ascertained that, between the participation frequencies of the sample, there was a statistically significant difference in the mean scores obtained from the 'willingness to learn' sub-scale of the Attitude Scale, whereas there was no statistically significant difference in the mean scores obtained from the 'affection and liking' sub-scale of the Attitude Scale. Following the ANOVA and Scheffe tests, it was found that the students participating in field trips six times or more had more positive attitudes towards the geography course than the students never participating in field trips and those that participated once or twice and 3-5 times in terms of the 'affection and liking' sub-scale. It was observed that, as the frequency of participation in trips, observations and field works went up during the geography course, the participants' attitudes towards the geography course became more positive.

As seen in Table 6, on the basis of the 'family's attitude to you variable, it was discerned that, between the attitude types of the parents of the sample, there was a statistically significant difference in the mean scores obtained from the 'affection and liking' and 'willingness to learn' sub-scales of the Attitude Scale. As a consequence of the ANOVA and Scheffe tests, it was ascertained that the students with democratic parents had more positive attitudes towards the geography course than the students with authoritarian parents in terms of the 'affection and liking' sub-scale, while the students, again, with democratic parents had more positive attitudes towards the geography course than the students with protectionist parents in terms of the 'willingness to learn' sub-scale.

As seen in Table 7, on the basis of the 'establishing relationship between geography and daily life' variable, it was found that, between the relationship statuses of the sample, there was a statistically significant difference in the mean scores obtained from the 'affection and liking' and 'willingness to learn' sub-scales of the Attitude Scale. As a result of the ANOVA and Scheffe tests, it was observed that the students who established relationships between geography and daily life had more positive attitudes towards the geography course than the students who failed to establish or those who sometimes established relationships between geography and daily life in terms of both the 'affection and liking' and 'willingness to learn' sub-scales. Moreover, it was discerned that the students who sometimes established relationships between geography and daily life had more positive attitudes towards the geography course than the students who failed to establish such relationships. It was ascertained that the students who were capable of establishing a relationship between geography and daily life had more positive attitudes towards the geography course than the other students.

Table 5. Statistics for the analysis of the sample on the basis of the 'participation in geography field trips' variable

\begin{tabular}{|c|c|c|c|c|c|c|c|}
\hline Sub-scale & Geography Field trip & Number & Mean & SD & $F$ & $\mathrm{p}$ & Post Hoc (Scheffe) \\
\hline \multirow{5}{*}{ Affection and Liking } & Never participated & 768 & 34.37 & 7.04 & \multirow{5}{*}{0.611} & \multirow{5}{*}{0.608} & \\
\hline & Once or twice & 102 & 35.29 & 6.02 & & & \\
\hline & 3-5 times & 19 & 33.84 & 7.34 & & & \\
\hline & 6 times and more & 10 & 35.20 & 7.96 & & & \\
\hline & Total & 899 & 34.47 & 6.94 & & & \\
\hline \multirow{5}{*}{ Willingness to Learn } & Never participated & 768 & 19.59 & 5.91 & \multirow{5}{*}{2.757} & \multirow{5}{*}{$0.041 *$} & \multirow{5}{*}{$6+>$ Never } \\
\hline & Once or twice & 102 & 20.93 & 5.69 & & & \\
\hline & 3-5 times & 19 & 21.36 & 6.33 & & & \\
\hline & 6 times and more & 10 & 22.60 & 6.29 & & & \\
\hline & Total & 899 & 19.81 & 5.91 & & & \\
\hline
\end{tabular}

${ }^{*} \mathrm{p}<0.05$

Table 6. Statistics for the analysis of the sample on the basis of the 'family's attitude to you' variable

\begin{tabular}{|c|c|c|c|c|c|c|c|}
\hline Sub-scale & family's attitude to you & $\mathrm{N}$ & Mean & SD & $\mathrm{F}$ & $\mathrm{p}$ & $\begin{array}{ll}\begin{array}{l}\text { Post } \\
\text { (LSD) }\end{array} & \text { Hoc } \\
\end{array}$ \\
\hline \multirow{4}{*}{ Affection and Liking } & Democratic & 257 & 35.39 & 6.96 & \multirow{4}{*}{5.243} & \multirow{4}{*}{$0.005^{*}$} & \multirow{4}{*}{ D-B, } \\
\hline & Protectionist & 515 & 34.38 & 6.60 & & & \\
\hline & Authoritarian & 127 & 32.99 & 7.97 & & & \\
\hline & Total & 899 & 34.47 & 6.94 & & & \\
\hline \multirow{4}{*}{ Willingness to Learn } & Democratic & 257 & 20.63 & 6.08 & \multirow{4}{*}{3.505} & \multirow{4}{*}{$0.030 *$} & \multirow{4}{*}{ K-D } \\
\hline & Protectionist & 515 & 19.52 & 5.61 & & & \\
\hline & Authoritarian & 127 & 19.33 & 6.62 & & & \\
\hline & Total & 899 & 19.81 & 5.91 & & & \\
\hline
\end{tabular}

${ }^{*} \mathrm{p}<0.05$ 
Table 7. Statistics for the analysis of the sample on the basis of the 'establishing relationship between geography and daily life' variable

\begin{tabular}{|c|c|c|c|c|c|c|c|}
\hline Sub-scale & $\begin{array}{l}\text { Relationship with daily } \\
\text { life }\end{array}$ & $\mathrm{N}$ & Mean & SD & F & $\mathrm{p}$ & Post Hoc (LSD) \\
\hline \multirow{4}{*}{ Affection and Liking } & Yes & 526 & 36.07 & 6.40 & \multirow{4}{*}{60.625} & \multirow{4}{*}{$0.000 *$} & \multirow{4}{*}{ E-H,E-K,H-K } \\
\hline & No & 87 & 28.08 & 8.22 & & & \\
\hline & Sometimes & 286 & 33.50 & 6.16 & & & \\
\hline & Total & 899 & 34.47 & 6.94 & & & \\
\hline \multirow{4}{*}{ Willingness to Learn } & Yes & 526 & 21.14 & 5.70 & \multirow{4}{*}{46.614} & \multirow{4}{*}{$0.000 *$} & \multirow{4}{*}{ E-H,E-K,H-K } \\
\hline & No & 87 & 15.39 & 6.52 & & & \\
\hline & Sometimes & 286 & 18.72 & 5.21 & & & \\
\hline & Total & 899 & 19.81 & 5.91 & & & \\
\hline
\end{tabular}

${ }^{*} \mathrm{p}<0.05$

Table 8. Statistics for the analysis of the sample on the basis of the 'use of social media' variable

\begin{tabular}{|c|c|c|c|c|c|c|c|}
\hline Sub-scale & Internet use (social media) & $\mathrm{N}$ & Mean & $\mathrm{SD}$ & $\mathrm{F}$ & $\mathrm{p}$ & Post Hoc (Scheffe) \\
\hline \multirow{4}{*}{ Affection and Liking } & Unable to use & 53 & 35.05 & 6.48 & \multirow{4}{*}{3.070} & \multirow{4}{*}{$0.027 *$} & \multirow{4}{*}{ Min-Max } \\
\hline & Using infrequently & 180 & 35.71 & 6.70 & & & \\
\hline & Using at normal frequency & 310 & 34.40 & 6.82 & & & \\
\hline & Using frequently & 356 & 33.83 & 7.17 & & & \\
\hline \multirow{4}{*}{ Willingness to Learn } & Unable to use & 53 & 20.67 & 5.89 & \multirow{4}{*}{3.171} & \multirow{4}{*}{$0.024 *$} & \multirow{4}{*}{ Min-Max } \\
\hline & Using infrequently & 180 & 20.82 & 5.75 & & & \\
\hline & Using at normal frequency & 310 & 19.70 & 5.70 & & & \\
\hline & Using frequently & 356 & 19.27 & 6.13 & & & \\
\hline
\end{tabular}

${ }^{*} \mathrm{p}<0.05$

Table 9. Statistics for the analysis of the sample on the basis of the 'establishing relationship between media and geography' variable

\begin{tabular}{|c|c|c|c|c|c|c|c|}
\hline Sub-scale & Relationship with media & $\mathrm{N}$ & Mean & $\mathrm{SD}$ & $\mathrm{F}$ & $\mathrm{p}$ & Post Hoc (LSD) \\
\hline \multirow{4}{*}{ Affection and Liking } & Yes & 314 & 34.92 & 7.01 & \multirow{4}{*}{11.588} & \multirow{4}{*}{$0.000 *$} & \multirow{4}{*}{ E-H, H-K } \\
\hline & No & 149 & 32.00 & 7.82 & & & \\
\hline & Sometimes & 436 & 35.00 & 6.39 & & & \\
\hline & Total & 899 & 34.47 & 6.94 & & & \\
\hline \multirow{4}{*}{ Willingness to Learn } & Yes & 314 & 20.85 & 6.11 & \multirow{4}{*}{12.180} & \multirow{4}{*}{$0.000 *$} & \multirow{4}{*}{ E-H, E-K, H-K } \\
\hline & No & 149 & 18.00 & 6.46 & & & \\
\hline & Sometimes & 436 & 19.68 & 5.41 & & & \\
\hline & Total & 899 & 19.81 & 5.91 & & & \\
\hline
\end{tabular}

$* \mathrm{p}<0.05$

As seen in Table 8, on the basis of the 'use of social media' variable, it was ascertained that, between the frequencies of social media use of the sample, there was a statistically significant difference in the mean scores obtained from the 'affection \& liking' and 'willingness to learn' sub-scales of the Attitude Scale. Along with the ANOVA and Scheffe tests, it was discerned that the students who infrequently used social media had more positive attitudes towards the geography course than the students who used social media more frequently in terms of both the 'affection and liking' and 'willingness to learn' sub-scales.

As seen in Table 9, on the basis of the 'establishing relationship between media and geography' variable, it was found that, between the relationship statuses of the sample, there was a statistically significant difference in the mean scores obtained from the 'affection \& liking' and 'willingness to learn' sub-scales of the Attitude Scale. With the ANOVA and Scheffe tests, it was observed that the students who established or those who sometimes established relationships between media and geography had more positive attitudes towards the geography course than the students who failed to establish a relationship between media and geography in terms of the 'affection and liking' sub-scale, while, in terms of the 'willingness to learn' sub-scale, the students who established relationships between media and geography had more positive attitudes towards the geography course than the students who sometimes established a relationship and those who failed to establish a relationship. Moreover, the students who sometimes established relationships had more positive attitudes towards the geography course than the students who failed to establish a relationship. 
As seen in Table 10, on the basis of the 'playing orienteering game' variable, it was ascertained that, between the orienteering statuses of the sample, there was a statistically significant difference in the mean scores obtained from the 'affection and liking' and 'willingness to learn' sub-scales of the Attitude Scale. As a consequence of the ANOVA and Scheffe tests, it was discerned that, in terms of both the 'affection and liking' and 'willingness to learn' sub-scales, the students who played the orienteering game had more positive attitudes towards the geography course than the students who did not play the orienteering game. Furthermore, the students who sometimes played the orienteering game had more positive attitudes towards the geography course than the students who did not play the orienteering game at all.

As seen in Table 11, on the basis of the 'teacher's use of student-centered active teaching' variable, it was found that, between the satisfaction statuses of the sample, there was a statistically significant difference in the mean scores obtained from the 'affection and liking' and 'willingness to learn' sub-scales of the Attitude Scale. Along with the ANOVA and Scheffe tests, it was discerned that, in terms of both the 'affection and liking' and 'willingness to learn' sub-scales, the students who responded positively to the teacher's use of student-centered active teaching in the course had more positive attitudes towards the geography course than the students who did otherwise. Moreover, the students who were partially satisfied with the teacher's use of student-centered active teaching in the course had more positive attitudes towards the geography course than the students who were not satisfied at all with the teacher's use of student-centered active teaching in the course.

Table 10. Statistics for the analysis of the sample on the basis of the 'playing orienteering game' variable

\begin{tabular}{|c|c|c|c|c|c|c|c|}
\hline Sub-scale & Orienteering & $\mathrm{N}$ & Mean & $\mathrm{SD}$ & $\mathrm{F}$ & $\mathrm{p}$ & Post Hoc (LSD) \\
\hline \multirow{4}{*}{ Affection and Liking } & Yes & 287 & 35.03 & 6.90 & \multirow{4}{*}{5.091} & \multirow{4}{*}{$0.006^{*}$} & \multirow{4}{*}{ E-H,H-K } \\
\hline & No & 134 & 32.77 & 7.32 & & & \\
\hline & Sometimes & 478 & 34.62 & 6.80 & & & \\
\hline & Total & 899 & 34.47 & 6.94 & & & \\
\hline \multirow{4}{*}{ Willingness to Learn } & Yes & 287 & 20.64 & 5.96 & \multirow{4}{*}{8.431} & \multirow{4}{*}{$0.000 *$} & \multirow{4}{*}{ E-H,H-K } \\
\hline & No & 134 & 18.11 & 6.05 & & & \\
\hline & Sometimes & 478 & 19.79 & 5.76 & & & \\
\hline & Total & 899 & 19.81 & 5.91 & & & \\
\hline
\end{tabular}

${ }^{*} \mathrm{p}<0.05$

Table 11. Statistics for the analysis of the sample on the basis of the 'teacher's use of student-centered active teaching' variable

\begin{tabular}{|c|c|c|c|c|c|c|c|}
\hline Sub-scale & $\begin{array}{l}\text { Teacher's use of } \\
\text { student-centered active teaching }\end{array}$ & $\mathrm{N}$ & Mean & SD & $\mathrm{F}$ & $\mathrm{p}$ & Post Hoc (LSD) \\
\hline \multirow{4}{*}{ Affection and Liking } & Yes & 583 & 36.08 & 6.29 & \multirow{4}{*}{59.846} & \multirow{4}{*}{$0.000 *$} & \multirow{4}{*}{ E-H,E-K,H-K } \\
\hline & No & 79 & 28.72 & 7.81 & & & \\
\hline & Sometimes & 237 & 32.44 & 6.64 & & & \\
\hline & Total & 899 & 34.47 & 6.94 & & & \\
\hline \multirow{4}{*}{ Willingness to Learn } & Yes & 583 & 21.17 & 5.37 & \multirow{4}{*}{53.863} & \multirow{4}{*}{$0.000^{*}$} & \multirow{4}{*}{ E-H,E-K,H-K } \\
\hline & No & 79 & 15.59 & 6.78 & & & \\
\hline & Sometimes & 237 & 17.87 & 5.70 & & & \\
\hline & Total & 899 & 19.81 & 5.91 & & & \\
\hline
\end{tabular}

${ }^{*} \mathrm{p}<0.05$

Table 12. Statistics for the analysis of the results obtained from the overall Attitude Scale in relation to the sample

\begin{tabular}{|c|c|c|c|c|c|}
\hline & N & Minimum & Maximum & Mean & Std. Deviation \\
\hline Total & 899 & 15.00 & 75.00 & 54.29 & 11.77 \\
\hline
\end{tabular}


It was found that the mean score obtained by the sample from the overall Attitude toward Geography Course Scale was $54.29 \pm 11.77$ points. The students' overall attitude towards the geography course was moderately positive.

\section{Discussion}

First of all, in this study, it was identified that, on the basis of the 'gender' variable, there was no statistically significant difference in the mean scores obtained from the 'affection and liking' and 'willingness to learn' sub-scales of the Attitude Scale. This finding was also in line with previous studies conducted on the topic [19-23]. This finding is of importance as it demonstrates that gender has no significant effect on students' attitudes towards the geography course in view of application of the same curriculum without any gender discrimination against certain secondary school students. In this respect, it may be asserted that female and male students developed analogous attitudes towards the geography course. Göcen [24] and Kaba [25] reported that students' attitudes towards the geography course differed significantly on the basis of students' gender. In the study by Sözen [26], it was stated indicating that female students had more positive attitudes towards the geography course than male students did. Şimşek [27] argued that, on the basis of the gender variable, there was a statistically significant difference in the mean scores obtained by prospective social studies teachers from the overall scale and the 'affection and liking' sub-scale, whereas there was no statistically significant difference in the mean scores obtained from the 'finding the course necessary' sub-scale. Tülümen [28] suggested that, on the basis of the gender variable, there was no statistically significant difference in the mean scores obtained from the 'liking' and 'interest' sub-scales, whilst female students had more positive attitudes in the light of the scores obtained from the 'importance' and 'expectation' sub-scales.

Second of all, in this study, it was found that, on the basis of the 'age' variable, there was a statistically significant difference in the mean scores obtained from the 'affection and liking' and 'willingness to learn' sub-scales of the Attitude Scale. The increase in the secondary school students' willingness to learn topics of geography as they grew older was a crucial finding of this study. On the other hand, in the study performed by Şimşek [27] on $4^{\text {th }}$ year undergraduate students enrolled at social studies teaching departments of different faculties of education across Turkey, there was no statistically significant difference in the students' attitudes towards the geography course on the basis of the age variable.

Third of all, in this study, it was found that, on the basis of the 'class year' variable, there was a statistically significant difference in the mean scores obtained from the 'affection and liking' and 'willingness to learn' sub-scales of the Attitude Scale. It was discerned that the $9^{\text {th }}$ and $12^{\text {th }}$ grade students had more positive attitudes towards the geography course than the $10^{\text {th }}$ grade students in terms of the 'affection and liking' sub-scale, while, in terms of the 'willingness to learn' sub-scale, the $10^{\text {th }}$ grade students had more positive attitudes towards the geography course than the $9^{\text {th }}$ and $12^{\text {th }}$ grade students. Moreover, the $11^{\text {th }}$ grade students had more positive attitudes towards the geography course than the $9^{\text {th }}$ grade students. At this juncture, the number of school hours devoted to the geography course at each class year attended by secondary school students and the attitudes and behaviors of teachers lecturing in each class year is likely to have effects on students' attitudes. In the study by Tülümen [28], it was ascertained that class year was a significant variable affecting secondary school students' attitudes towards the geography course in terms of the 'liking' and 'interest' sub-scales, while it was not a significant variable affecting students' attitude scores in terms of the 'importance' and 'expectation' sub-scales. Aydın et al. [19] demonstrated that there was a statistically significant difference in attitudes towards the geography course between $9^{\text {th }}$ grade and $10^{\text {th }}$ grade students. Sözen [26] found that $3^{\text {rd }}$ and $4^{\text {th }}$ year undergraduate students had more positive attitudes towards the geography course than $1^{\text {st }}$ and $2^{\text {nd }}$ year undergraduate students.

Additionally, in this study, it was discerned that, on the basis of the 'school type' variable, there was a statistically significant difference in the mean scores obtained from both sub-scales of the Attitude Scale. It was ascertained that the Science High School students had less positive attitudes toward the geography course than the students of other school types in terms of the 'affection and liking' sub-scale, while the Social Science High School students had more positive attitudes towards the geography course than the students of other school types in terms of the 'willingness to learn' sub-scale. As the number of school hours devoted to geography course is smaller at Science High Schools, the attitude of Science High School students towards the geography course is likely to be less positive. Previous studies have shown that school type affects attitudes towards the geography course [25, 28]. In the study by Sözen [26], there was no statistically significant difference in students' attitude scores on the basis of class year; however, the attitude scores of Anatolian High School graduates were higher. In previous studies, it was stated that the geography course was lectured under cultural courses at Vocational High Schools, and students attached less importance to this course than they attached to their vocational courses [29, 30]. Thus, at certain types of high school, less importance is attributed to the geography course. At all types of high school, the geography course is lectured through the same curriculum. However, as students of Anatolian and Science High Schools prefer to pay more attention to quantitative courses, and as the effect of the geography course on the success of such students in the higher education entrance exam is relatively small, these students are likely to be less interested in the geography course. 
Moreover, in this study, it was ascertained that, on the basis of the 'participation in geography field trips' variable, there was a statistically significant difference in the mean scores obtained from the 'willingness to learn' sub-scale of the Attitude Scale, whereas there was no statistically significant difference in the mean scores obtained from the 'affection and liking' sub-scale. It was observed that the students participating in geography field trips six times or more had more positive attitudes towards the geography course than the students participating in geography field trips never, once or twice and 3-5 times. It was discerned that, as the frequency of participation in geography field trips went up during the geography course, the participants' attitudes towards the geography course became more positive. Krakowka [31] suggested that participation in geography field trips enabled students to acquire significant learning experiences. Reinforcing geographic knowledge and skills with real-life experience is of great importance to geography instruction and ensures that the learning of students becomes more permanent. Fuller et al. [32] highlighted that field and open space activities had positive effects on instruction of the geography course. Presenting real-life experiences and acquiring first-hand data were deemed crucial in the framework of field works, as well as providing students with different perspectives and diverse skills. Shakil et al. [33] underlined that educational field trips empowered students to cope with learning problems, provided students with practice-oriented activities and made the learning process even more interesting for students. In the study by Aslan [34], it was put forward that field trips tempted student participants to learn by doing and living in natural environments and comprehend the difference between theory and practice.

Furthermore, in this study, it was discerned that, on the basis of the 'family's attitude to you' variable, there was a statistically significant difference in the mean scores obtained from both sub-scales of the Attitude Scale. It was ascertained that the students with democratic parents had more positive attitudes towards the geography course than the students with authoritarian parents in terms of the 'affection and liking' sub-scale, while the students, again, with democratic parents had more positive attitudes towards the geography course than the students with protectionist parents in terms of the 'willingness to learn' sub-scale. Attitudes are not natural characteristics owned by human beings as of birth. They are developed later. The family setting which is most suitable to the psycho-social development of youngsters and children is a place that is dominated by love and respect in which a democratic relationship between the parents and the child prevails [35].

What is more, in this study, it was found that, on the basis of the 'establishing relationship between geography and daily life' variable, there was a statistically significant difference in the mean scores obtained from both sub-scales of the Attitude Scale. It was observed that the students who established relationships between geography and daily life had more positive attitudes towards the geography course than the students who failed to establish such a relationship or those who sometimes established relationships between geography and daily life in terms of both the 'affection and liking' and 'willingness to learn' sub-scales. Besides, it was discerned that the students who sometimes established relationships between geography and daily life had more positive attitudes towards the geography course than the students who failed to establish a relationship. In studies performed in Turkey, it was asserted that, as geography is a land-based course, it is not possible to provide students with sufficient information on the importance of geography and its use in daily life [36, 37]. Studies have stressed the importance of demonstrating the relationship of information and courses offered at the school setting with daily life. This is due to the fact that relating lessons learnt in the geography course to daily life and using them in daily life will encourage students to like the course better and be more interested in the course, and it will help them be more successful in this course [38-42].

It was also ascertained in this study that, on the basis of the 'use of social media' variable, there was a statistically significant difference in the mean scores obtained from both sub-scales of the Attitude Scale. It was discerned that the students who used social media infrequently had more positive attitudes towards the geography course than the students who used social media more frequently in terms of both sub-scales. The participants who use the internet and social media infrequently are likely to be more active in their social lives, and thus, they may have more opportunities to perceive the geographic landscape. In the study by Çetin et al. [43], of all participants responding to the question "Do you ever examine data posted by social media sites which share information on geography?", $78 \%$ said 'yes', $10 \%$ said 'partially' and 2\% said 'no'. The use of social media and technology may enable students to gain awareness on geography as it is the case for every other field.

Additionally, it was found that, on the basis of the 'establishing relationship between media and geography' variable, there was a statistically significant difference in the mean scores obtained from both sub-scales of the Attitude Scale. The students who established or those who sometimes established relationships between media and geography had more positive attitudes towards the geography course than the students who failed to establish a relationship between media and geography in terms of the 'affection and liking' sub-scale, while, in terms of the 'willingness to learn' sub-scale, the students who established a relationship between media and geography had more positive attitudes towards the geography course than the students who sometimes established such a relationship and those who failed to establish a relationship. Moreover, the students who sometimes established relationships had more positive attitudes towards the geography course than the students who failed to establish a relationship. The students who were capable of establishing a relationship between media and 
geography had much more positive attitudes towards the geography course. It was ascertained that secondary school students who were able to relate films, TV series, news and game shows to geography had more positive attitudes towards the geography course. Hence, this finding is of importance as it demonstrates that students will be capable of reviewing geography through a geographic perspective also in the media.

In this study, it was also ascertained that, on the basis of the 'playing orienteering game' variable, there was a statistically significant difference in the mean scores obtained from both sub-scales of the Attitude Scale. It was discerned that, in terms of both sub-scales, the students who played the orienteering game had more positive attitudes towards the geography course than the students who did not play the orienteering game. Furthermore, the students who sometimes played the orienteering game had more positive attitudes towards the geography course than the students who did not play the orienteering game. Orienteering is a game which requires the players to reach the target on the field as soon as possible based on a given map and find directions systematically in nature. It is a sports activity in which competitors race against time so as to find out targets, which are previously concealed in a forestland or in a region inside the city, as soon as possible with the help of a map. It is also included in ecotourism activities such as paragliding, rafting, equestrianism and paintball. With the help of this game, students are able to perceive the geographical landscape better. In this respect, it was found that the secondary school students who played the orienteering game had more positive attitudes towards the geography course.

Finally, this study found that, on the basis of the 'teacher's use of student-centered active teaching' variable, there was a statistically significant difference in the mean scores obtained from both sub-scales of the Attitude Scale. In terms of both sub-scales, the students who responded positively had more positive attitudes towards the geography course than the students who did otherwise. Moreover, the students who were partially satisfied with the method had more positive attitudes towards the geography course than the students who were not satisfied at all with the method. Secondary school students' attitudes towards the geography course differ on the basis of the methods implemented in the course. If geography teachers use interactive and student-oriented methods in the geography course, it is likely that students will have more positive attitudes towards the course. Demirkan and Saraçoğlu [44] also noted that teachers typically resorted to the direct instruction technique, a conventional method, in the teaching process.

Geography as a science necessitates the heavy use of technology. Contemporary instruction methods and techniques employed by the teacher throughout the course affect students' approaches toward the course positively and raise their interest in the course. Hence, students' attitudes toward courses are transformed in the positive direction. It was ascertained that well-planned field activities and trips
[31], cooperative learning [45], the 5E model [46], geography course supported with science-fiction films [47], the use of interactive infographics in education [48], methods and techniques relying on brain-based learning theory [5] and teaching and instruction carried out via the method of trip and observation [49] were more effective than conventional methods.

In the research, the mean score obtained by the secondary school students from the overall Attitude toward the Geography Course Scale was 54.29 points. The maximum score which can be obtained from the scale is 75 points. Thus, this mean score indicated that the sample had a positive attitude toward the geography course. Moreover, it was found that the secondary school students had positive attitudes toward the geography course $[28,50]$. Studies performed on undergraduate students also had findings in a similar vein [51, 52]. Students who have positive attitudes toward the school or a course become more successful in the course, whereas students who have negative attitudes become less successful [16]. Furthermore, in the study by Jana and Patra [23], it was set forth that there was a highly positive correlation between attitude toward geography and success in geography. Only if students have geography teachers who enjoy their profession fully and perform their profession flawlessly, they will find geography interesting in the classroom setting and demonstrate positive attitudes towards the geography course.

\section{Conclusions and Recommendations}

In conclusion, it was found that, in general, the secondary school students had moderately positive attitudes towards the geography course. It may be asserted that the female and male students developed similar attitudes towards the geography course. In addition to this, in this study, it was found that participation in geography trips positively affected the desire to learn. Moreover, it was observed that the students who established a relationship between geography and daily life had a more positive attitude towards the geography course. The students who could establish a relationship between media and geography also showed a much more positive attitude towards the geography course. It was determined that the secondary school students who could associate movies, TV series, news and game shows with geography had more positive attitudes towards the geography course. Moreover, the student-centered active teaching method of teachers developed a positive attitude towards the geography course. For the geography course to accomplish its goals, it is essential that students develop a positive attitude toward it. In this respect, teachers should begin with urging students to comprehend the necessity and importance of the geography course. Students who realize how and where lessons to be learnt will be used in daily life and those who are aware of the importance of lessons to be learnt may be expected to develop positive attitudes toward 
the course. The factors that affect students' attitudes in the geography course should be considered. Students should be encouraged to comprehend the necessity of learning geography. Lecturing the course categorically in the field if deemed necessary is likely to entice students to adopt positive attitudes toward it. Encouraging students to participate in the course actively, creating learning settings well-aligned with the changing Geography Curriculum, using highly diverse instruction materials and student-oriented instruction methods in the course and promoting students' geographical awareness may help students develop positive attitudes toward the geography course.

\section{REFERENCES}

[1] Bednarz, S. W. Geography for Life: National Geography Standards. National Geographic Society, Washington, 1994.

[2] Özçağlar, A. Coğrafyaya Giriş [Introduction to Geography]. (5th Edition). Ankara: Ümit Ofset Publishing House, 2009.

[3] Edwards, J. Geographic Literacy and Defoe's Complete Englishmen: Mere Bookcases v, 2012.

[4] National Assessment of Educational Progress (NAEP). The Nation's Report Card: Geography, 2001. Retrieved from: Http://nces.ed.gov/pubsearch/pubsinfo.asp?pubid=2002484

[5] Ünlü, M. Coğrafya Öğretimi [Geography Teaching]. Ankara. Pegem Academy publications, 2014.

[6] Ministry of National Education of Turkey. Coğrafya Dersi Öğretim Programı [Geography Lesson Education Program], Ankara, 2018.

[7] Kerski, J.J. A National Assesment of GIS in American High Schools. International Research in Geographical and Environmental Education, 10 (1), 72-84, 2001.

[8] Kerski, J.J. The implementation and effectiveness of geographic information systems technology and methods in secondary education, Journal of Geography, 102(3), 128-137, 2003.

[9] Aydın, F \& Güngördü, E. Coğrafya eğitiminde özel öğretim yöntemleri [Special teaching methods in geography education]. Ankara, Pegem Academy, 2015.

[10] Kağıtçıbaşı, Ç. Yeni İnsan ve İnsanlar [New People and People]. (10th Edition) Istanbul, Evrim Publishing, 2006.

[11] İnceoğlu, M. Tutum, alg1, iletişim [Attitude, perception, communication] (5th Edition). Istanbul, Beykent University, 2010.

[12] Eagly, A.H., \& Chaiken, S. The psychology of attitudes. Orlando, FL: Harcourt Brace Jovanovich College Publishers, 1993.

[13] Çetin, O. Teknoloji ve Öğrenme-Öğretme Kuramları [Technology and Learning-Teaching Theories]. (G. Ekici (Ed.), Öğrenme-Öğretme Kuramları ve Uygulamadaki Yansımaları [Learning-Teaching Theories and Their
Reflections in Practice], (8: 904-946). Ankara: Pegem publisher, 2016.

[14] Salta, K., \& Tzougraki, C. Attitudes toward chemistry among 11th grade students in high schools in Greece. Science Education, 88(4), 535-547, 2004.

[15] Maxwell, J. C. Kazanan Tutum. [Winning Attitude]. Istanbul: Kurtiş Printing House, 2002.

[16] Mccoach, D.B. A Validation Study of the School Attitude Assessment Survey. Measurement and Evolution in Counseling and Development, 35(2), 66-78, 2002.

[17] Karasar, N. Scientific Research Method. Ankara, Nobel Publishing, 2006.

[18] Demir, S. B. \& Koç, H. Geography Courses Attitude Scale: Development, Validity And Reliability Study, Turkish Studies, 8(8), 1765-1777, 2013.

[19] Aydın, F., Coşkun, M. \& Kaya, H. The Attitudes ff Commercial Vocational High School Students Towards Geography Lesson (Elbistan Example), Çankırı Karatekin University, Journal of Social Sciences Institute, 1, 183-203, 2010.

[20] Lannes, D. Rumjanek, V. M. Velloso, A. \& de Meis, L. Brazilian Schools: Comparing Students' Interests with What is Being Taught. Educational Research, 44 (2): 157-179, 2002.

[21] Özdemir, Ü. High School Students' Attitudes towards Geography Courses (Karabuk Sample-Turkey). World Applied Sciences Journal, 17 (3): 340-346, 2012.

[22] Tosun, C. \& Genc, M., Adaptation of science attitude scale developed for primary school students to Turkish: Validity and reliability studies. Elementary Education Online, 14(3), 946-960, 2015. http://dx.doi.org/10.17051/io.2015.08787

[23] Jana, A.K \& Patra, A. Attitude and Achievement in Geography: A Stydy on Bengali Medium Students, International Journal of Education and Psychological Research (IJEPR), 6, 2, 72-77, 2017.

[24] Göcen, C. The attitudes of 12th grade students towards geography lesson. Unpublished Master Thesis. Gazi University Institute of Educational Sciences, Ankara, 2011.

[25] Kaba, R. 9th class students towards the course of geography (Kahramanmaraş sample). Unpublished Master Thesis. Atatürk University, Institute of Educational Sciences, Erzurum, 2016.

[26] Sözen, E. The Opinions of Undergraduate Students during the Undergraduate Education on Geography Content Lectures, MANAS Journal of Social Studies, 8(1): 38-53, 2019.

[27] Şimşek, M. Self-efficacy levels and attitudes of prospective social studies teachers towards geography. Unpublished Doctoral Thesis, Marmara University Institute of Educational Sciences, İstanbul, 2016.

[28] Tülümen, M. Examination of high school students' anxiety and attitudes towards geography lessons by various variables, Unpublished Master Thesis, Karabük University, Institute of Educational Sciences, Karabük, 2018.

[29] Gül, C. Determining the reasons of diversities in behaviors shown by the students in vocational training to the teachers 
of cultural courses and vocational courses. Unpublished Master Thesis, Marmara University Institute of Science, İstanbul, 2008.

[30] Karadağ, O. Research the level of learning abilities of 10th class students in industrial vocational high schools in Bağc1lar district is questioned. Unpublished Master Thesis, Marmara University Institute of Educational Sciences, İstanbul, 2009.

[31] Krakowka, A. R. Field trips as valuable learning experiences in geography courses. Journal of Geography, 111(6), 236-244, 2012.

[32] Fuller, I., Edmondson, S., France, D., Higgitt, D., \& Ratinen, I. International Perspectives On The Effectiveness of Geography Fieldwork For Learning, Journal of Geography in Higher Education, 30(1), 89-101, 2006.

[33] Shakil, A. F., Faizi, W., N. \& Hafeez, S. The need and importance of field trips at higher level in Karachi, Pakistan. International Journal of Academic Research in Business and Social Sciences, 2(1), 1-17, 2011.

[34] Aslan, A. Determination of prospective teachers' attitudes on scientific field trips and viıews on hydroelectric power plants. Journal of Research in Informal Environments, 4(1), 61-83, 2019.

[35] Kuzgun, Y. \& Eldeleklioğlu, J. Development of Parental Attitude Scala. Uludağ University Journal of Education Faculty, 12 (1), 69-77, 1999.

[36] Aydın, F. Social Sciences High School Students Opinions towards Teaching of Geography Course, Kastamonu Education Journal, 20(3), 1035-1050, 2012.

[37] Kenger, G. 9th grade students, capability of using geographic concepts which are learned at scholl on daily life. Unpublished Master Thesis. Marmara University Institute of Social Sciences, İstanbul, 2010.

[38] Smith, M.U. \& Siegel, H. Knowing, believing, and understanding: What goals for science education? Science \& Education, 13(6), 553-582, 2004.

[39] Choi, H. J. \& Johnson, S. D. The Effect of Context-Based Video Instruction on Learning and Motivation in On-Line Courses. The American Journal of Distance Education, 19(4), 215-227, 2005

[40] Bal, A.P. Examination of Teacher Candidates' Achievement Levels and Views Towards The Routine and Real Life Problems. Pegem eğitim ve öğretim dergisi, 5(3), 273-290, 2015. DOI:http://dx.doi.org/10.14527/pegegog.2015.015

[41] Köse, E.Ö \& Gül, Ş. Primary School Teacher Candidates' Levels of Associating Biology Information with Daily Life, Amasya Education Journal, 5(1), 84-103, 2016. doi: 10.1753 9/aej.90627

[42] Günes, T. \& Öner, Z. The Effects of Consept Based Learning Approach towards Students' Environmental Attitudes, International Journal of Social Sciences and Education Research, 3(1), 345-355, 2016.

[43] Çetin, M., Özkaya, A., Keskin, M., \& Özdemir, Ö. Social Media Platforms Contribution to The Process of Teaching Geography In Turkey, The Journal of Social Sciense, 6(33), 456-472, 2019.
[44] Demirkan, Ö. \& Saraçoğlu, G. (2016). Views of Anatolian High School Teachers about Teaching Methods and Techniques They Use in Class, the Journal of International Lingual, Social and Educational Sciences, 2(1), 1-11.

[45] Koçyiğit, M. \& Engin, A.O. The Effect of Cooperative Learning Method on the Students' Achievement and Attitudes in Geography Lesson, TURAN Center for Strategic Researches, 11(43), 174-188, 2019. DOI: http://dx.doi.org/1 $0.15189 / 1308-8041$

[46] Mercan, S.I. 5e Geography Course Of Activity Based on Learning Model Effect of Learning Environment on The Community Process, Journal of World of Turks [ZfWT] , 9(3), 161-176, 2017.

[47] Biber, S.K \& Kubaş, A. The Impact of Science Fiction Movies on the Attitudes of 10th Grade Students towards Geography Course, HAYEF: Journal of Education, 14(2): 165-182, 2017. DOI: 10.26650/hayef.2017.14.2.0019

[48] Çifçi, T. Perceptions of the Gifted Student on the Geography Lesson. e-International Journal of Educational Research, 6(3), 87-100, 2015. https://doi.org/10.19160/e-ijer.62438

[49] Özgen, N. A Different Approach to Physical Geography Teaching Method: Trip - Observation Supported Education, International Journal of Geography and Geography Education, Say1: 23, 373-388, 2011.

[50] Gerber, R.V. Attitudes to Geography in Australia, Australian Geographer, 32(2), 221-239, 2001.

[51] Ulusoy, K. \& Gülüm, K. Attitudes Of The Department of Social Sciences Teaching Students' towards The History and Geography Courses, Dumlupinar University, Journal of Social Sciences, 25, 149-160, 2009.

[52] Gökçe, N. Social Studıes Teacher Candidates' Attitudes towards Geography Course. NWSA (e-Journal of New World Sciences Academy), 5(4): 2071- 2083, 2010. 